\title{
Model Pertumbuhan Ekonomi Kabupaten Kota Sulawesi Barat Menggunakan Pendekatan Regresi Spasial Data Panel
}

\author{
Muhammad Arafat Abdullah*1, Asrirawan² \\ ${ }^{1}$ Program Studi Kehutanan, Universitas Sulawesi Barat \\ ${ }^{2}$ Program Studi Statistika, Universitas Sulawesi Barat \\ e-mail:*1arafat@unsulbar.ac.id, ${ }^{2}$ asrirawan@ unsulbar.ac.id,
}

\begin{abstract}
Abstrak
Pertumbuhan ekonomi suatu daerah merupakan salah satu indikator ekonomi yang sangat penting dari daerah tersebut. Salah satu indikator yang digunakan dalam mengukur pertumbuhan ekonomi adalah nilai Produk Domestik Regional Bruto (PDRB). Pertumbuhan ekonomi Sulawesi Barat melambat pada Triwulan I 2020 akibat adanya efek covid. Secara spesifik untuk tiap kabupaten akan diteliti bagaimana model dari pertumbuhan ekonominya. Ketergantungan spasial (spatial dependence) merupakan salah satu faktor penting yang perlu dipertimbangkan dalam menganalisa pertumbuhan ekonomi suatu wilayah. Pertumbuhan ekonomi khususnya di wilayah kabupaten kota Sulawesi Barat dengan melibatkan independensi spasial dan faktor-faktor yang mempengaruhinya cukup menarik dikaji. Secara lebih mendalam, digunakan model spasial panel. Digunakan empat faktor dalam mengukur pertumbuhan ekonomi, yaitu Pendapatan asli daerah $\left(X_{1}\right)$, belanja modal $\left(X_{2}\right)$, banyaknya pengangguran $\left(X_{3}\right)$, dan rata-rata lama sekolah $\left(X_{4}\right)$. Setelah dilakukan analisis, model yang sesuai untuk pertumbuhan ekonomi Sulawesi Barat adalah model Spasial SAR dengan efek acak dengan variabel yang berpengaruh terhadap pertumbuhan ekonomi Sulawesi Barat adalah variabel rata-rata lama sekolah $\left(X_{4}\right)$ dengan nilai koefisien positif.
\end{abstract}

Kata kunci: Efek acak, PDRB, SAR

\section{PENDAHULUAN}

Ekonomi Sulawesi Barat melambat pada triwulan I 2020. Pengaruh Covid- 19 diperkirakan masih memberikan dampak terhadap aktivitas ekonomi Sulawesi Barat. Permintaan masyarakat belum terlalu kuat apalagi momentum Ramadhan yang sudah lewat. Realisasi pertumbuhan ekonomi tercatat sebesar 4,92\% (yoy) lebih rendah dibandingkan triwulan IV 2019 sebesar 6,37\% (yoy). Produksi komoditas perkebunan seperti kelapa sawit dan kakao masih tergolong rendah sejalan dengan pola musiman. Normalisasi demand masyarakat setelah tumbuh kuat pada triwulan IV 2019 mempengaruhi lesunya perdagangan retail. Dari sisi pengeluaran, aktivitas perdagangan ekspor juga melambat karena rendahnya permintaan Tiongkok sebagai negara tujuan utama CPO Sulawesi Barat.

Realisasi penanaman modal masih rendah karena investor masih wait and see serta belum adanya proyek infrastruktur baru yang bernilai besar di Sulawesi Barat (Bank Indonesia, 2020). Perekonomian Sulawesi Barat triwulan II-2020 yang diukur berdasarkan Produk Domestik Regional Bruto (PDRB) atas dasar harga berlaku mencapai 11,32 triliun rupiah, sedangkan atas dasar harga konstan 2010 mencapai 7,92 triliun rupiah. Ekonomi Sulawesi Barat triwulan II-2020 jika dibandingkan dengan triwulan yang sama tahun 2019 (y-on-y) mengalami kontraksi sebesar 0,78 persen.

Menurut lapangan usaha, pertumbuhan tertinggi adalah sebesar 5,30 persen pada lapangan usaha Informasi dan Komunikasi. Adapun dari sisi pengeluaran, kontraksi terendah terjadi pada komponen Pengeluaran Konsumsi Rumah Tangga sebesar 0,74. Ekonomi Sulawesi Barat triwulan II-2020 secara q-to-q mengalami kontraksi sebesar 1,27 persen. Pertumbuhan tertinggi dicapai oleh lapangan usaha Informasi dan Komunikasi sebesar 5,38 persen. Dari sisi pengeluaran pertumbuhan tertinggi dicapai oleh komponen Pengeluaran Konsumsi Pemerintah sebesar 50,96 persen. Secara kumulatif (triwulan I-II) 2020 jika dibandingkan dengan kondisi yang sama tahun 2019 (c-to-c), ekonomi Sulawesi Barat tumbuh hingga 2,00

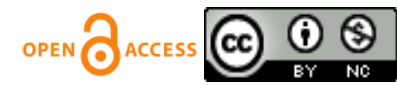


persen. Pertumbuhan tertinggi dari sisi lapangan usaha adalah Informasi dan Komunikasi sebesar 7,01 persen. Sedangkan dari sisi pengeluaran, pertumbuhan tertinggi terjadi pada komponen Pengeluaran Konsumsi Rumah Tangga sebesar 1,60 persen. Pada skala regional di Kawasan Sulawesi Maluku Papua, pertumbuhan ekonomi wilayah yang tertinggi pada triwulan II-2020 (q-to-q) terjadi di Papua sebesar 3,45 persen. Secara y-on-y, pertumbuhan ekonomi tertinggi pada triwulan II-2020 terjadi di Papua sebesar 4,52 persen. Sehingga secara q-to-q dan y-on-y, Sulawesi Barat menempati masing-masing posisi ke lima dan enam untuk kawasan Sulampua. Dan secara kumulatif hingga triwulan II (semester I) 2020, pertumbuhan tertinggi terjadi di Papua yang sebesar 3,00 persen (BPS Sulawesi Barat, 2020).

Ketergantungan spasial (spatial dependence) merupakan salah satu faktor penting yang perlu dipertimbangkan dalam menganalisa pertumbuhan ekonomi suatu wilayah. Hal tersebut berdasarkan pada pandangan bahwa suatu wilayah tidak dapat diperlakukan sebagai unit yang berdiri sendiri, yang disebabkan oleh adanya interaksi sosial ekonomi antarwilayah di antaranya melalui perdagangan, aliran modal, migrasi, difusi teknologi, dan pertukaran informasi (Nijkamp dan Poot, 1998). Interaksi sosial ekonomi antarwilayah itu akan memunculkan ketergantungan spasial pada pertumbuhan ekonomi yang disebut juga oleh Lesage (1999) sebagai terjadinya spatial spillover. Tselios (2009) menambahkan bahwa ketergantungan spasial tersebut akan semakin kuat pengaruhnya terhadap pertumbuhan ekonomi wilayah-wilayah yang bertetanggaan, karena interaksi sosial ekonomi antarwilayah yang bertetanggaan tersebut relatif tidak ada hambatan (Aspiansyah dan Damayanti, 2019). Le Gallo dan Fingleton (2014) menyatakan bahwa adanya saling ketergantungan antarwilayah membuat sebagian besar penelitian regional menggunakan teknik ekonometrika spasial untuk menganalisis pertumbuhan ekonomi regional.

Berdasarkan pemaparan di atas, penelitian tentang pertumbuhan ekonomi khususnya di wilayah kabupaten kota Sulawesi Barat dengan melibatkan independensi spasial dan faktor-faktor yang mempengaruhinya cukup menarik dikaji. Model yang dibentuk akan mejadi dasar karakteristik pertumbuhan ekonomi wilayah satu yang saling berkaitan dengan wilayah lain. Fokus permasalahan dalam penelitian ini adalah pemodelan pertumbuhan ekonomi di wilayah Sulawesi Barat dan faktor-faktor yang mempengaruhi pertumbuhan ekonomi pada wilayah tersebut menggunakan Regresi Spasial Data Panel dengan pembatasan masalah pada kasus pertumbuhan ekonomi dari tahun 2014 sampai dengan tahun 2019.

\subsection{Regresi Data Panel}

Data panel merupakan gabungan antara data cross-section dan data time series. Pada data panel, unit cross-section yang sama disurvei pada beberapa periode waktu. Jadi, data panel memiliki dimensi ruang dan waktu. Jika masing-masing unit cross-section memiliki jumlah pengamatan time series yang sama maka data panel tersebut dinamakan data panel seimbang (balanced panel data), sebaliknya jika jumlah pengamatan time series berbeda pada masing-masing unitmaka disebut data panel tidak seimbang (unbalanced pane ldata) (Gujarati, 2005). Model regresi panel secara umum dapat dinyatakan dalam bentuk berikut (Hsiao, 2003).

$$
y_{i t}=\alpha_{i t}+\boldsymbol{\beta} \mathbf{X}_{\mathbf{i t}}+u_{i t} ; i=1,2,3, \ldots, N ; t=1,2,3, \ldots, T
$$

dengan

$y_{i t}$ : unit cross section ke-i untuk periode waktu ke-t

$\mathbf{X}$ : vektor observasi pada variabel independen

$\boldsymbol{\beta}$ : vektor konstanta

$\alpha_{i t}$ : intersep objek ke-i waktu ke-t

$u_{i t}$ : error regresi untuk grup ke-i waktu ke-t

$u_{i t} \sim \operatorname{IIDN}\left(0, \sigma^{2}\right)$

\subsection{Matriks Pembobot Spasial}

Matriks pembobot spasial merupakan matriks yang menyatakan hubungan dari wilayah pengamatan yang berukuran $n \times n$ dan disimbolkan dengan $\mathbf{W}$. Adapun bentuk umum dari matriks pembobot spasial ( $\mathbf{W}$ ) adalah: 
https://jurnal.unsulbar.ac.id/index.php/saintifik

$$
\mathbf{W}=\left[\begin{array}{cccc}
w_{11} & w_{12} & \ldots & w_{1 n} \\
w_{21} & w_{22} & \ldots & w_{2 n} \\
\vdots & \vdots & \ddots & \vdots \\
w_{n 1} & w_{n 2} & \ldots & w_{n n}
\end{array}\right]
$$

Elemen-elemen dari $\mathbf{W}$ diatas adalah $w_{i j}$ dengan $i$ adalah baris pada elemen $\mathbf{W}$ dan $j$ adalah kolom pada elemen $\mathbf{W}$ dan merupakan wilayah di sekitar lokasi pengamatan $i$. Elemen $\mathbf{W}$ di atas dapat memiliki dua nilai yaitu nol dan satu. Dimana nilai $w_{i j}=1$ untuk wilayah yang berdekatan dengan lokasi pengamatan, sedangkan nilai $w_{i j}=0$ untuk wilayah yang tidak berdekatan dengan lokasi pengamatan. Secara umum terdapat empat tipe interaksi atau persinggungan batas wilayah, yaitu:

a) Rook Contiguity, yaitu Rook contiguity ialah persentuhan sisi wilayah satu dengan sisi wilayah yang lain yang bertetangga. Adapun nilai dari tiap elemennya yaitu jika lokasi $i$ dan $j$ bersentuhan sisi maka $w_{i j}=1$ . Namun, jika lokasi $i$ dan $j$ tidak bersentuhan sisi maka $w_{i j}=0$.

b) Bishop contiguity, yaitu persentuhan titik sudut wilayah satu dengan wilayah lain yang bertetangga. Adapun nilai dari tiap elemennya yaitu jika lokasi $i$ dan $j$ bersentuhan titik sudut maka $w_{i j}=1$. Namun, jika lokasi $i$ dan $j$ tidak bersentuhan titik sudut maka $w_{i j}=0$.

c) Queen Contiguity, yaitu persentuhan sisi maupun titik sudut wilayah satu dengan wilayah yang lain yaitu gabungan rook contiguity dan bishop contiguity. Adapun nilai dari tiap elemennya yaitu jika lokasi $i$ dan $j$ bersentuhan sisi atau titik sudut maka $w_{i j}=1$. Namun, jika lokasi $i$ dan $j$ tidak bersentuhan sisi ataupun titik sudut maka $w_{i j}=0$.

d) Customized contiguity, metode ini mendefinisikan $w_{i j}=1$ untuk region yang bersisian atau region dengan karakteristik yang sama dengan region yang mendapat perhatian, dan $w_{i j}=0$ untuk region lainnya.

(Anselin, 1988).

\subsection{Model Regresi Panel}

Common Effect Model (CEM) Pendekatan CEM ini diasumsikan bahwa nilai intersep dan slope masingmasing variabel adalah sama untuk semua unit cross section dan timeseries

$$
y_{i t}=\alpha_{i t}+\boldsymbol{\beta} \mathbf{X}_{\mathbf{i t}}+u_{i t} ; i=1,2,3, \ldots, N ; t=1,2,3, \ldots, T
$$

Fixed Effect Model (FEM) Pendekatan FEM diasumsikan bahwa nilai slope masing-masing variabel adalah tetap namun nilai intersep berbeda-beda untuk setiap unit cross section dantetap untuk setiap unit time series. Model pendekatan FEM yakni sebagai berikut

$$
y_{i t}=\alpha_{i t}+\boldsymbol{\beta} \mathbf{X}_{\mathbf{i t}}+u_{i t} ; i=1,2,3, \ldots, N ; t=1,2,3, \ldots, T
$$

Random Effect Model (REM) Pendekatan REM diasumsikan bahwa intersep $\alpha_{i}=\alpha_{0}+\varepsilon_{i}$ dengan mean $\alpha_{0}$ dan $\varepsilon_{i}$ disebut juga variabel laten merupakan error random dengan mean 0 dan varians $\sigma_{\varepsilon}^{2}$. Model pendekatan REM yakni sebagai berikut.

$$
\begin{gathered}
y_{i t}=\alpha_{i t}+\boldsymbol{\beta} \mathbf{X}_{\mathbf{i t}}+q_{i t} ; i=1,2,3, \ldots, N ; t=1,2,3, \ldots, T \\
q_{i t}=\varepsilon_{i}+u_{i t}
\end{gathered}
$$

$\varepsilon_{i}:$ komponen error cross section

$u_{i t}$ : kombinasi antara komponen cross section dan time series

dengan asumsi bahwa $u_{i t} \sim N\left(0, \sigma_{u}^{2}\right), \varepsilon_{i} \sim N\left(0, \sigma_{\varepsilon}^{2}\right), E\left(\varepsilon_{i}, u_{i t}\right)=0, E\left(\varepsilon_{i}, \varepsilon_{j}\right)=0$ dimana $i \neq j$; $E\left(u_{i t}, u_{i s}\right)=E\left(u_{i t}, u_{j t}\right)=E\left(u_{i t}, u_{j s}\right)$ dimana $i \neq j$ dan $t \neq s$. 
https://jurnal.unsulbar.ac.id/index.php/saintifik

\subsection{Model Regresi Panel Spasial}

Model regresi spasial untuk data panel memiliki efekspesifik spasial tanpa efek interaksi spasial sebagai berikut.

$$
y_{i t}=\boldsymbol{\beta} \mathbf{X}_{\mathbf{i t}}+\mu_{i}+\varepsilon_{i t} ; i=1,2,3, \ldots, N ; t=1,2,3, \ldots, T
$$

Model regresi data panel yang terdapat interaksi di antaraunit-unit spasial akan memiliki variabel dependen spasial lagatau spasial proses pada error yang disebut juga dengan modelspasial lag (SAR) dan model spasial error (SEM). Model Spasial Lag (SAR) dapat dinayatakan sebagai berikut:

$$
y_{i t}=\delta \sum_{j=1}^{N} W_{i j} y_{j t}+\boldsymbol{\beta} \mathbf{X}_{\mathbf{i t}}+\mu_{i}+\varepsilon_{i t} ; i=j=1,2,3, \ldots, N ; t=1,2,3, \ldots, T
$$

$\delta$ : koefisien spasial autoregressive

$W_{i j}$ : matriks pembobot spasial

$y_{j t}:$ variabel dependen

Model Spasial Error (SEM) dapat dinyatakan sebagai berikut:

$y_{i t}=\boldsymbol{\beta} \mathbf{X}_{\mathbf{i t}}+\mu_{i}+\phi_{i t} ; i=j=1,2,3, \ldots, N ; t=1,2,3, \ldots, T$

$$
\begin{aligned}
& \phi_{i t}=\rho \sum_{j=1}^{N} W_{i j} \phi_{i t}+\varepsilon_{i t} \\
& \phi: \text { spasial auto korelasi } \\
& \rho: \text { :koefisien auto korelasi spasial }
\end{aligned}
$$

\section{METODE PENELITIAN}

\subsection{Data dan Variabel Penelitian}

Data yang digunakan pada penelitian ini adalah data sekunder yang diperoleh dari BPS Sulawesi Barat tentang Pengukuran Kerja Makro Ekonomi dan Sosial Sulawesi Barat. Penelitian ini menggunakan dua jenis variabel, yaitu variabel dependen dan variabel independen seperti yang disajikan pada tabel 1 berikut.

Tabel 1 Variabel Penelitian

\begin{tabular}{|c|l|c|}
\hline Variabel & \multicolumn{1}{|c|}{ Keterangan } & Satuan \\
\hline$Y$ & PDRB atas dasar harga konstan & Milyar Rupiah \\
\hline$X_{1}$ & Pendapatan Asli Daerah & Ribu Rupiah \\
\hline$X_{2}$ & Belanja Modal & Ribu Rupiah \\
\hline$X_{3}$ & Jumlah Pengangguran & Jiwa \\
\hline$X_{4}$ & Rata-rata lama sekolah & Tahun \\
\hline
\end{tabular}

Penelitian ini menggunakan data panel seimbang, terdiri atas data time series dari tahun 2014 hingga 2019 dan data cross section adalah 6 kabupaten yang ada di Sulawesi Barat, yakni Majene, Polewali Mandar, Mamasa, Mamuju, Pasangkayu dan Mamuju Tengah. Definisi operasional untuk masing-masing variabel dependen dan independen yang digunakan adalah:

a. Produk Domestik Regional Bruto atas dasar harga konstan (Y) adalah nilai tambah barang dan jasa yang dihitung menggunakan harga berlaku pada satu tahun tertentu sebaga idasar.

b. Pendapatan Asli Daerah $\left(\mathrm{X}_{1}\right)$ adalah penerimaan yang berasal dari sumber- sumber pendapatan daerah yang terdiri dari pajak daerah, retribusi daerah, bagian laba BUMD, penerimaan dari dinas-dinas dan penerimaan lain-lain.

c. Belanja Modal $\left(\mathrm{X}_{2}\right)$ adalah pengeluaran yang digunakan untuk pembelian/pengadaan atau pembangunan aset tetap berwujud yang nilai manfaatnya lebih dari setahun, dan atau pemakaian jasa dalam melaksanakan 
https://jurnal.unsulbar.ac.id/index.php/saintifik

program dan kegiatan pemerintah daerah.

d. Tenaga Kerja $\left(\mathrm{X}_{3}\right)$ adalah jumlah pengangguran

e. Rata-rata lama sekolah $\left(\mathrm{X}_{5}\right)$ adalah jumlah tahun belajar penduduk usia 15 tahun ke atas yang telah diselesaikan dalam pendidikan formal.

\subsection{Tahapan penelitian}

Secara umum langkah-langkah yang dilakukan dalam penelitian ini adalah sebagai berikut:

a. Mendapatkan dan membuat deskripsi variabel-variabel yang digunakan

b. Mengestimasi parameter dari model tersebut dengan spasial fixed effect danspasial random effect pada masing-masing model SAR, SEM dan SDM.

c. Menetapkan matriks pembobot spasial $\square W \square$

d. Menentukan model yang dipilih berdasarkan kriteria kebaikan model

e. Menguji asumsi kenormalan residual, identik, independen, dan tidak terjadi multi kolinearitas pada model. Melakukan penanggulangan jika asumsi tidak terpenuhi.

\section{HASIL DAN PEMBAHASAN}

\subsection{Eksplorasi Data}

Eksplorasi data ini dilakukan untuk memberikan gambaran dan informasi yang berguna dari data tanpa mengambil kesimpulan secara umum. Bentuk eksplorasi data pada penelitian ini adalah dengan membuat grafik pergerakan variabel-variabel PDRB atas dasar harga konstan dari waktu ke waktu untuk tiap kabupaten di Provinsi Sulawesi Barat.

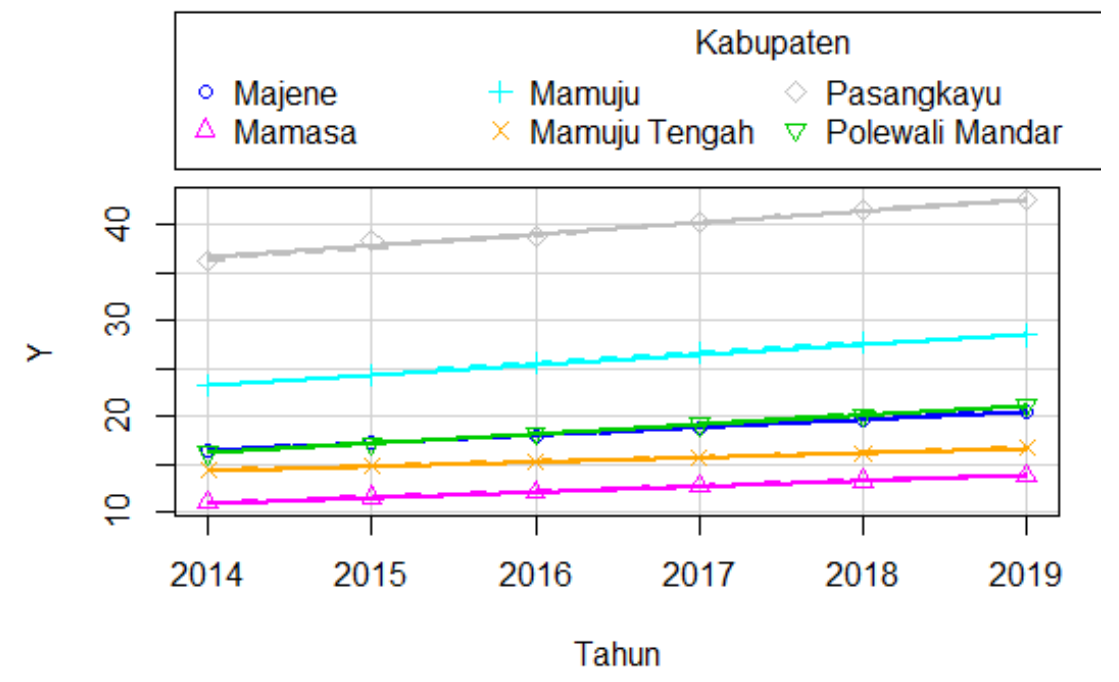

Gambar 1. Pergerakan PDRB Atas Dasar Harga Konstan

Dari Gambar 1 terlihat bahwa kesepuluh daerah tersebut memiliki kecenderungan meningkat dari tahun ke tahun untuk variabel PDRB atas dasar harga konstan. Dari keenam kabupaten di Provinsi Sulawesi Barat terlihat bahwa Kabupaten Pasangkayu merupakan kabupaten yang memiliki PDRB atas dasar harga konstan tertinggi dari tahun 2014 sampai tahun 2019. Sedangkan Kabupaten Mamasa adalah kabupaten dengan tingkat PDRB atas dasar harga konstan terendah di antara kabupaten-kabupaten lainnya. Berdasar plot PDRB atas dasar harga konstan pada Gambar 5.1, maka sebelum dilakukan analisis pada data yang tersedia, dilakukan transformasi logaritma natural terlebih dahulu pada variabel respon maupun variabel penjelas. Sehingga yang menjadi variabel respon atau $\mathrm{Y}$ pada penelitian ini adalah logaritma natural dari PDRB atas dasar harga konstan, dan variabel penjelas atau $\mathrm{X}_{1}, \mathrm{X}_{2}, \mathrm{X}_{3}$ dan $\mathrm{X}_{4}$ masing-masing adalah logaritma natural dari pendapatan asli daerah (PAD), belanja modal, jumlah pengangguran dan rata-rata lama sekolah. Transformasi pada variabel penjelas dilakukan untuk memperkecil kemungkinan terjadinya masalah dalam proses analisis sebab variabel penjelas yang digunakan memiliki satuan yang berbeda-beda. 


\subsection{Analisis Data Panel}

Tahapan berikutnya adalah melakukan analisis data panel, yaitu melakukan pendugaan model awal dengan metode pemodelan data panel. Selanjutnya untuk menguji kesesuaian atau kebaikan model dari ketiga metode pada teknik pendugaan data panel digunakan uji Chow dan uji Hausman.

\section{Menduga Model Data Panel}

Model dalam analisis data panel ada tiga jenis, yaitu model gabunga, model tetap dan model acak. Sebelum penelitian dilakukan, telah ditetapkan bahwa taraf nyata $(\alpha)$ pada penelitian ini adalah 0.05 .

\section{a. Model Gabungan}

Dari hasil analisis data panel dengan menggunakan pendekatan model gabungan, diperoleh hasil seperti yang disajikan pada tabel berikut.

Tabel 2 Hasil Pendugaan Model Gabungan

\begin{tabular}{|c|c|c|}
\hline Variabel & Koefisien & Nilai-p \\
\hline $\mathrm{C}$ & -1.959 & 0.36493 \\
\hline $\mathrm{X}_{1}$ & -0.267 & 0.09125 \\
\hline $\mathrm{X}_{2}$ & 0.273 & 0.09667 \\
\hline $\mathrm{X}_{3}$ & -0.197 & 0.36717 \\
\hline $\mathrm{X}_{4}$ & 2.528 & 0.04067 \\
\hline$F_{\text {Hitung }}$ & 2.391 & 0.07212 \\
\hline$R^{2}$ & 0.236 & \\
\hline Adjusted $R^{2}$ & 0.137 & \\
\hline
\end{tabular}

Sumber: Olah data, 2020

Berdasarkan hasil analisis dengan model gabungan pada Tabel 2 di atas, diperoleh bahwa variabel ratarata lama sekolah $\left(\mathrm{X}_{4}\right)$ adalah satu-satunya variabel penjelas yang berpengaruh nyata terhadap terhadap PDBR atas dasar harga konstan. Selain itu, variabel pendapatan asli daerah $\left(\mathrm{X}_{1}\right)$ dan jumlah pengangguran $\left(\mathrm{X}_{3}\right)$ berpengaruh negative terhadap PDBR atas dasar harga konstan walaupun pengaruhnya tidak nyata. Terjadi kontradiksi pada variabel pendapatan asli daerah $\left(\mathrm{X}_{1}\right)$, secara teori pendapat asli daerah seharusnya berpengaruh positif terhadap PDBR atas dasar harga konstan (Rarung 2016). Hal ini mungkin terjadi karena data untuk variabel pendapatan asli daerah untuk setiap kabupaten mengalami kelonjakan yang sangat tinggi pada tahun 2019.

Koefisien determinasi model $\left(R^{2}\right)$ maupun koefisien determinasi terkoreksi (Adjusted $R^{2}$ ) diperoleh berturut-turut 0.236 dan 0.137 . Hal ini menunjukkan bahwa kontribusi variabel penjelas yang digunakan dalam menysusun model sangatlah kecil yaitu sebesar $23.6 \%$ saja sedangkan sekitar $76.4 \%$ adalah kontribusi dari variabel penjelas lainnya yang tidak dimasukkan ke dalam model.

\section{b. Model Tetap}

Berdasarkan hasil analisis dengan model tetap pada Tabel 3, diperoleh bahwa variabel rata-rata lama sekolah $\left(\mathrm{X}_{4}\right)$ berpengaruh nyata terhadap PDBR atas dasar harga konstan. Sedangkan variabel belanja modal $\left(\mathrm{X}_{2}\right)$ menunjukkan pengaruh yang negative walaupun tidak nyata. Dan hasil ini bertentangan dengan teori bahwasanya belanja modal $\left(\mathrm{X}_{2}\right)$ seharusnya berpengaruh positif terhadap PDBR atas dasar harga konstan (Rarung 2016).

Koefisien determinasi model $\left(R^{2}\right)$ maupun koefisien determinasi terkoreksi (Adjusted $R^{2}$ ) diperoleh berturut-turut 0.857 dan 0.807 . Hal ini menunjukkan bahwa kontribusi variabel penjelas yang digunakan dalam menysusun model cukup besar yaitu sebesar $85.7 \%$ saja sedangkan sekitar $14.3 \%$ adalah kontribusi dari variabel penjelas lainnya yang tidak dimasukkan ke dalam model. Pendugaan model data panel dengan menggunakan model tetap disajikan pada tabel berikut:

Tabel 3 Hasil Pendugaan Model Tetap

\begin{tabular}{|l|c|c|}
\hline Variabel & Koefisien & Nilai-p \\
\hline
\end{tabular}


https://jurnal.unsulbar.ac.id/index.php/saintifik

\begin{tabular}{|c|c|c|}
\hline $\mathrm{X}_{1}$ & 0.009 & 0.5555 \\
\hline $\mathrm{X}_{2}$ & -0.008 & 0.6149 \\
\hline $\mathrm{X}_{3}$ & 0.029 & 0.1997 \\
\hline $\mathrm{X}_{4}$ & 1.772 & $1.871 \mathrm{e}-08$ \\
\hline$F_{\text {Hitung }}$ & 38.86 & $1.3024 \mathrm{e}-10$ \\
\hline$R^{2}$ & 0.857 & \\
\hline Adjusted $R^{2}$ & 0.807 & \\
\hline
\end{tabular}

Sumber: Olah data, 2020

\section{c. Model Acak}

Dari hasil analisis data panel dengan menggunakan pendekatan model gabungan, diperoleh hasil seperti yang disajikan pada tabel berikut.

Tabel 4 Hasil Pendugaan Model Acak

\begin{tabular}{|c|c|c|}
\hline Variabel & Koefisien & Nilai-p \\
\hline $\mathrm{C}$ & -0.576 & 0.1771 \\
\hline $\mathrm{X}_{1}$ & 0.008 & 0.5679 \\
\hline $\mathrm{X}_{2}$ & -0.007 & 0.6274 \\
\hline $\mathrm{X}_{3}$ & 0.029 & 0.1997 \\
\hline $\mathrm{X}_{4}$ & 1.776 & $1.155 \mathrm{e}-15$ \\
\hline$\chi_{\text {Hitung }}^{2}$ & 155.902 & $2.22 \mathrm{e}-16$ \\
\hline$R^{2}$ & 0.834 & \\
\hline Adjusted $R^{2}$ & 0.812 & \\
\hline
\end{tabular}

Sumber: Olah data, 2020

Berdasarkan hasil analisis dengan model tetap pada Tabel 4 di atas, diperoleh bahwa variabel rata-rata lama sekolah $\left(\mathrm{X}_{4}\right)$ berpengaruh nyata terhadap PDBR atas dasar harga konstan. Sedangkan variabel belanja modal $\left(\mathrm{X}_{2}\right)$ menunjukkan pengaruh yang negative walaupun tidak nyata. Dan hasil ini bertentangan dengan teori bahwasanya belanja modal $\left(\mathrm{X}_{2}\right)$ seharusnya berpengaruh positif terhadap PDBR atas dasar harga konstan (Rarung 2016).

Koefisien determinasi model $\left(R^{2}\right)$ maupun koefisien determinasi terkoreksi (Adjusted $R^{2}$ ) diperoleh berturut-turut 0.834 dan 0.812 . Hal ini menunjukkan bahwa kontribusi variabel penjelas yang digunakan dalam menysusun model cukup besar yaitu sebesar $83.4 \%$ saja sedangkan sekitar $16.6 \%$ adalah kontribusi dari variabel penjelas lainnya yang tidak dimasukkan ke dalam model.

\section{Pemilihan Model Data Panel}

Setelah menduga model data panel, baik model gabungan, model tetap dan model acak, maka langkah selanjutnya adalah memilih model yang tepat untuk menggambarkan PDBR atas dasar harga konstan dari ketiga model tersebut.

\section{a. Uji Chow}

Pengujian ini dilakukan untuk memilih apakah model yang akan digunakan adalah model gabungan atau model pengaruh tetap. Hipotesis awal $\left(\mathrm{H}_{0}\right)$ pada uji Chow adalah tidak terdapat pengaruh individu terhadap model (model mengikuti model gabungan) dan hipotesis tandingannya $\left(\mathrm{H}_{1}\right)$ adalah terdapat satu atau lebih pengaruh individu terhadap model (model mengikuti model pengaruh tetap). Hasil pengujian dengan uji Chow ditampilkan pada tabel berikut:

Tabel 5 Hasil Uji Chow

\begin{tabular}{|l|l|}
\hline Model & $\log (\mathrm{Y}) \sim \log \left(\mathrm{X}_{1}\right)+\log \left(\mathrm{X}_{2}\right)+\log \left(\mathrm{X}_{3}\right)+\log \left(\mathrm{X}_{4}\right)$ \\
\hline$F_{\text {hitung }}$ & 782.38 \\
\hline Nilai-p & $2.2 \mathrm{e}-16$ \\
\hline
\end{tabular}

Sumber: Olah data, 2020 
Berdasarkan Tabel 5 di atas, diperoleh nilai-p $<\alpha(0.05)$, maka hipotesis nol ditolak. Sehingga sudah cukup bukti untuk menyatakan bahwa model sementara yang lebih sesuai digunakan adalah model pengaruh tetap. Selanjutnya dilakukan uji kesesuaian model antara model pengaruh tetap dan model pengaruh acak melalui uji Hausman.

\section{b. Uji Hausman}

Uji Hausman digunakan untuk memilih model yang sesuai antara model pengaruh tetap dengan model pengaruh acak. Hipotesis awal $\left(\mathrm{H}_{0}\right)$ yang digunakan pada uji ini adalah model pengaruh acak lebih sesuai digunakan dengan hipotesis tandingannya $\left(\mathrm{H}_{1}\right)$ adalah model pengaruh tetap lebih sesuai digunakan. Tabel 5.6 menampilkan hasil perhitungan uji Hausman.

Tabel 6 Hasil Uji Hausman

\begin{tabular}{|c|l|}
\hline Model & $\log (\mathrm{Y}) \sim \log \left(\mathrm{X}_{1}\right)+\log \left(\mathrm{X}_{2}\right)+\log \left(\mathrm{X}_{3}\right)+\log \left(\mathrm{X}_{5}\right)$ \\
\hline$\chi^{2}{ }_{\text {hitung }}$ & 4.709 \\
\hline Nilai-p & 0.3184 \\
\hline
\end{tabular}

Sumber: Olah data, 2020

Berdasarkan perhitungan pada Tabel 6 menunjukan nilai-p $>\alpha(0.05)$, maka hipotesis nol diterima. Sehingga kurang cukup bukti untuk menyatakan bahwa model sementara yang lebih sesuai digunakan adalah model pengaruh tetap. Dari hasil uji Chow dan uji Housman di atas, maka model pendekatan yang digunakan dalam penelitian ini adalah model pengaruh acak. Dalam penelitian ini jumlah unit lintas individu $(\mathrm{N})$ sebanyak 6 dan jumlah unit deret waktu (T) sebanyak 6 dan keenam unit lintas individu diambil tidak secara acak, melainkan adalah jumlah keseluruhan kabupaten yang ada di Provinsi Sulawesi Barat pada rentang waktu 2014-2019.

\subsection{Analisis Data Penel Spasial}

Pada analisis data panel, diperoleh model yang digunakan sementara adalah model pengaruh acak. Adapun hasil analisis data panel spasial adalah sebagai berikut:

\section{Matriks Pembobot Spasial}

Sebelum melakukan analisis spasial pada model pengaruh acak, maka terlebih dahulu haruslah membentuk matriks pembobot spasial yang akan digunakan dalam menggambarkan kedekatan atar area. Pendekatan yang digunakan untuk menentukan matriks pembobot spasial pada penelitian ini adalah dengan konsep persinggungan, yaitu konsep ratu catur. Selanjutnya, matriks pembobot spasial yang telah diperoleh kemudian dilakukan normalisasi terlebih dahulu. Metode yang digunakan untuk menormalisasikan matriks pembobot spasial tersebut adalah metode normalisasi baris.

\section{Uji Efek Spasial}

Untuk mengetahui adanya efek spasial perlu dilakukan uji dependensi spasial pada data dengan menggunakan beberapa metode pengujian. Pada penelitian ini, pengujian dependensi spasial menggunakan uji autokorelasi spasial dan uji Pengganda Lagrange (Langrange Multiplier, LM).

\section{a. Uji Autokorelasi Spasial}

Hasil uji auto korelasi dengan menggunakan Randomization-based test diperoleh hasil sebagai berikut:

Tabel 7 Uji Normalitas Auto korelasi Spasial

\begin{tabular}{|c|c|}
\hline Model & Model pengaruh acak \\
\hline Nilai-p & 0.04 \\
\hline
\end{tabular}

Sumber: Olah data, 2020

Berdasarkan Tabel 7 di atas, diperoleh hasil bahwa nilai-p < $\alpha(0.05)$ sehingga dapat disimpulkan bahwa terdapat auto korelasi spasial pada model pengaruh acak yang diperoleh pada analisis data panel sebelumnya. Sehingga analisis data panel dengan rekomendasi model sementara adalah model pengaruh acak dapat dilanjutkan ke analisis data panel spasial. 
https://jurnal.unsulbar.ac.id/index.php/saintifik

\section{b. Uji Pengganda Lagrange}

Pemilihan model spasial dilakukan dengan Pengganda Lagrange (LM) sebagai identifikasi awal. Pengganda Lagrange (LM). Uji LM digunakan untuk mendeteksi dependensi spasial dengan lebih spesifik yaitu dengan dependensi dalam lag, error atau keduanya (lag dan error). Apabila LM lag dan LM error tidak signifikan maka dapat disimpulkan tidak terjadi dependensi baik pada lag maupun error. Hasil pengujian Pengganda Lagrange (LM) disajikan pada tabel berikut:

Tabel 8 Perhitungan Uji Pengganda Lagrange

\begin{tabular}{|c|c|c|}
\hline Koefisien & Nilai LM & Nilai-p \\
\hline SAR & 9.1604 & 0.002473 \\
\hline SEM & 1.4551 & 0.2277 \\
\hline
\end{tabular}

Sumber: Olah data, 2020

Pada Tabel 8, terlihat bahwa nilai-p $<\alpha(0.05)$ untuk koefisien SAR Hal ini menunjukkan bahwa terdapat ketergantungan lag spasial sehingga perlu dilanjutkan pada pembentukan model SAR. Sedangkan nilai-p $>\alpha$ (0.05) untuk koefisien SEM, yang artinya terdapat tidak ketergantungan galat spasial sehingga tidak perlu dilanjutkan pada pembentukan model SEM. Sehingga model sementara yang untuk analisis data panel spasial adalah model pengaruh acak dengan pendekatan spasial SAR.

1. Pemilihan Model Data Panel Spasial

Pemilihan model yang akan digunakan dalam pemodelan data panel dapat dilakukan dengan menggunakan uji Houssman dengan membandingkan antara model pengaruh acak SAR dan model pengaruh tetap SAR. Hasil dari pengujian dapat dilihat pada tabel berikut:

Tabel 9 Uji Housman Spasial

\begin{tabular}{|c|c|c|}
\hline Model & $\chi_{\text {hitung }}^{2}$ & Nilai-p \\
\hline Model Acak & 0.8405 & 0.9329 \\
\hline Model Tetap & & \\
\hline
\end{tabular}

Sumber: Olah data, 2020

Berdasarkan Tabel 9 di atas, diperoleh hasil nilai-p $>\alpha(0.05)$, sehingga dapat disimpulkan bahwa model data panel spasial yang akan digunakan dalam penelitian ini adalah model pengaruh acak dengan pengaruh spasial SAR.

2. Pendugaan Parameter

Model yang diduga parameternya adalah model data panel spasial dengan model pengaruh acak dengan model lag spasial. Hasil pendugaan untuk model tersebut ditampilkan pada Tabel 10. Berdasarkan Tabel 10, diperoleh bahwa hanya variabel rata-rata lama sekolah (X4) yang berpengaruh nyata terhadap PDBR atas dasar harga konstan. Dan juga diperoleh bahwa variabel auto korelasi spasial $(\lambda)$ berpengaruh nyata terhadap model.

Tabel 10 Pendugaan model data panel spasial

\begin{tabular}{|c|c|c|}
\hline Variabel & Koefisien & Nilai- $p$ \\
\hline $\mathrm{C}$ & -0.083 & 0.7521 \\
\hline $\mathrm{X}_{1}$ & 0.005 & 0.3534 \\
\hline $\mathrm{X}_{2}$ & -0.005 & 0.3778 \\
\hline $\mathrm{X}_{3}$ & 0.005 & 0.5488 \\
\hline $\mathrm{X}_{4}$ & 0.389 & $1.002 \mathrm{e}-05$ \\
\hline$\lambda$ & 0.788 & $2.2 \mathrm{e}-16$ \\
\hline
\end{tabular}

Sumber: Olah data, 2020

\section{Pengecekan Asumsi}

Setelah mendapatkan model data panel spasial dengan model pengaruh acak dengan model lag spasial, maka selanjutnya akan dilakukan pemeriksaan asumsi yang berkaitan dengan metode pendugaan parameter 
pada model tersebut. Berdasarkan gambar dibawah, maka diperoleh bahwa galat pada model data panel spasial menyebar normal. Hal ini disebabkan karena titik-titik pada gambar berbentuk mendekati garis linier.

\section{Plot Q-Q Normal}

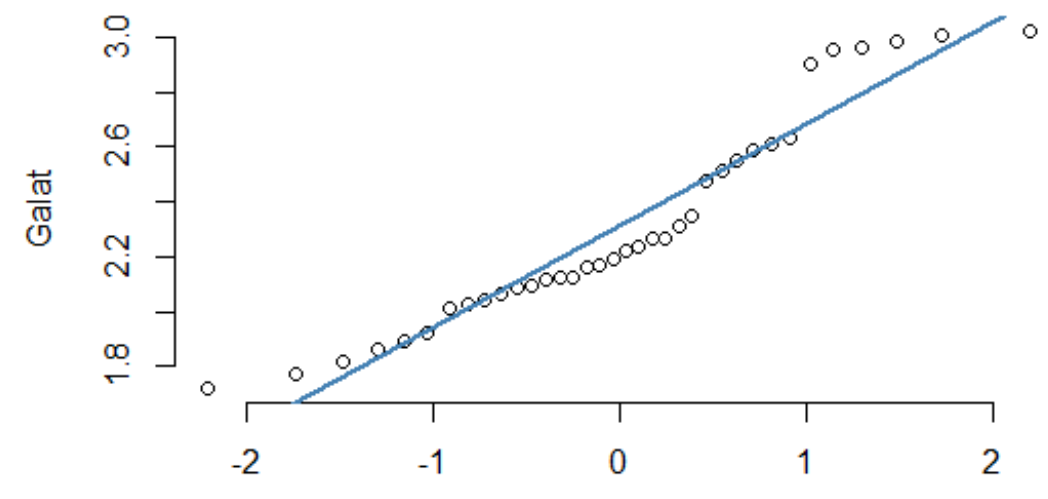

Normal Score

Gambar 2. Plot Kuantil-Kuantil untuk Galat model data panel spasial dengan model pengaruh acak dengan model SAR

\section{Model Akhir}

Berdasarkan hasil perhitungan pada analisis data panel spasial, didapatkan bahwa model yang diduga adalah model data panel spasial dengan model pengaruh acak dengan model SAR. Sehingga model yang sesuai untuk logaritma natural PDRB atas dasar harga konstan pada enam kabupaten di Provinsi Sulawesi Barat dari tahun 2014 sampai 2019 berdasarkan variabel-variabel yang berpengaruh nyata adalah:

$$
\hat{y}_{i t}=0.788 \sum W_{i j} y_{j t}+0.389 X 4_{i t}
$$

Karena di awal analisis digunakan transformasi logaritma natural untuk memodelkan data, maka untuk kepentingan interpretasi, koefisien dari variabel yang berpengaruh nyata terhadap variabel Y, yaitu rata-rata lama sekolah ditransformasi baik. Diperoleh hasil transformasi dari 0.389 sebesar 1,4755. Artinya bahwa untuk penambahan 1 tahun dari rata-rata lama sekolah, akan meningkatkan nilai PDRB sebesar Rp. 1,4755 Milyar.

\section{KESIMPULAN}

Berdasarkan hasil analisis, diperoleh kesimpulan model yang sesuai dengan pertumbuhan ekonomi Sulawesi barat adalah model Spasial SAR dengan efek acak dengan faktor yang berpengaruh adalah rata-rata lama sekolah. Dengan nilai pengaruh sebesar 1,4755.

\section{DAFTAR PUSTAKA}

Anselin, Luc, 1988, Spatial Econometrics: Methods and Models, Kluwer Academic Publisher, Netherlands. Aspiansyah dan Damayanti, A., 2019, Model Pertumbuhan Ekonomi Indonesia: Peranan Ketergantungan Spasial Indonesia's Economic Growth Model: The Role of Spatial Dependence, Jurnal Ekonomi dan Pembangunan Indonesia. Vol. 19 No. 1 Januari 2019, hal 62-83.

Badan Pusat Statistik Sulawesi Barat, 2020, Pertumbuhan Ekonomi, Berita Resmi Statistik BPS No. 37/08/76/Th.XIV, 05 Agustus 2020 Sulawesi Barat.

Bank Indonesia. 2020. Laporan Perekonomian Provinsi Sulawesi Barat. Volume14 No. 2, Mei 2020. Sulawesi Barat: Kantor Perwakilan Bank Indonesia Provinsi Sulawesi Barat.

Gujarati, D. N., 2005, Basic Econometric 5th Edition, Mc Graw Hill Companies, New York. 
https://jurnal.unsulbar.ac.id/index.php/saintifik

Hsiao, C., 2003, Analysis of Panel Data, Cambridge University Press, New York.

Le Gallo, J., \& Fingleton, B., 2014,. Regional growth and convergence empirics. In M. Fischer \& P. Nijkamp (eds), Handbook of Regional Science, Springer, Berlin, Heidelberg:

Lesage, J. P., \& Fischer, M. M., 2008, Spatial growth regressions: model specifification, estimation and interpretation. Spatial Economic Analysis, 3(3), 275-304. doi:https://doi.org/10.1080/ 17421770802353758.

Nijkamp, P., \& Poot, J., 1998, Spatial perspectives on new theories of economic growth. The Annals of Regional Science, 32(1), 7-37. doi:https://doi.org/10.1007/s001680050061.

Tselios, V., 2009, Growth and Convergence In Income Per Capita And Income Inequality In The Regions Of The EU. Spatial Economic Analysis, 4(3), 343-370. doi:https://doi.org/10.1080/17421770903114711. 